\title{
Functional Labor Market Areas for Chile
}

\author{
Francisco Rowe ${ }^{1}$, José Manuel Casado-Díaz ${ }^{2}$, Lucas Martínez-Bernabéu ${ }^{3}$ \\ ${ }^{1}$ University of Liverpool, Liverpool, UK (email: F.Rowe-Gonzalez@liverpool.ac.uk) \\ ${ }^{2}$ University of Alicante, Alicante, Spain (email: jmcasado@ua.es) \\ ${ }^{3}$ University of Alicante, Alicante, Spain (email: lucas.martinez@ua.es) \\ Received: 21 July 2017/Accepted: 22 July 2017
}

\begin{abstract}
Administrative areas are arbitrarily designed and do not necessarily reflect the geographical patterns of socio-economic and labor market activity. Labor market areas (LMAs) are required to analyze spatial labor market activity and provide a framework to guide spatially-explicit employment policy development. This resource describes a data source of a set of recently created labor market areas for Chile.
\end{abstract}

\section{Background}

In 2009, a comprehensive review of Chile's territorial economic performance by the OECD highlighted underutilized potential in the use of regional assets and capacity to boost national economic productivity (OECD 2009). To redress these deficiencies, recommendations to transition to a territorial policy approach were emphasized and Casado-Díaz et al. (2017) developed a set of functional Labor Market Areas (LMAs) to assess spatial labor market activity, and to guide future employment policy development.

\section{Description of the resource}

The data set includes 62 LMAs, providing full coverage of the Chilean territory (Figure 1). The LMAs were delineated by means of the algorithm described in Casado-Díaz et al. (2017) which uses evolutionary computation to implement an optimization process. In this process the overall internal cohesion of LMAs is maximized subject to restrictions of minimum levels of self-containment and population size which are applied to each of the resulting LMAs. The method is an extension of the algorithm proposed by MartínezBernabeu et al. (2012). The regionalization process was performed using commuting data from the CHilean Internal Migration (CHIM) database (Rowe, Bell 2013). Data from the 1982, 1992, and 2002 Chilean Housing and Population census were appended to the set of LMAs to produce a geographic information database. The database contains information on the resident population by five-year age groups, sex, labor force status, industry sector, and occupation and is available in a shapefile format. Together with this database, a correspondence file for the matching municipality and labor market areas is made available.

\section{Potential applications}

This database provides a unique opportunity to better understand the economic geography of Chile over a period of twenty years, between 1982 and 2002. This was a period 


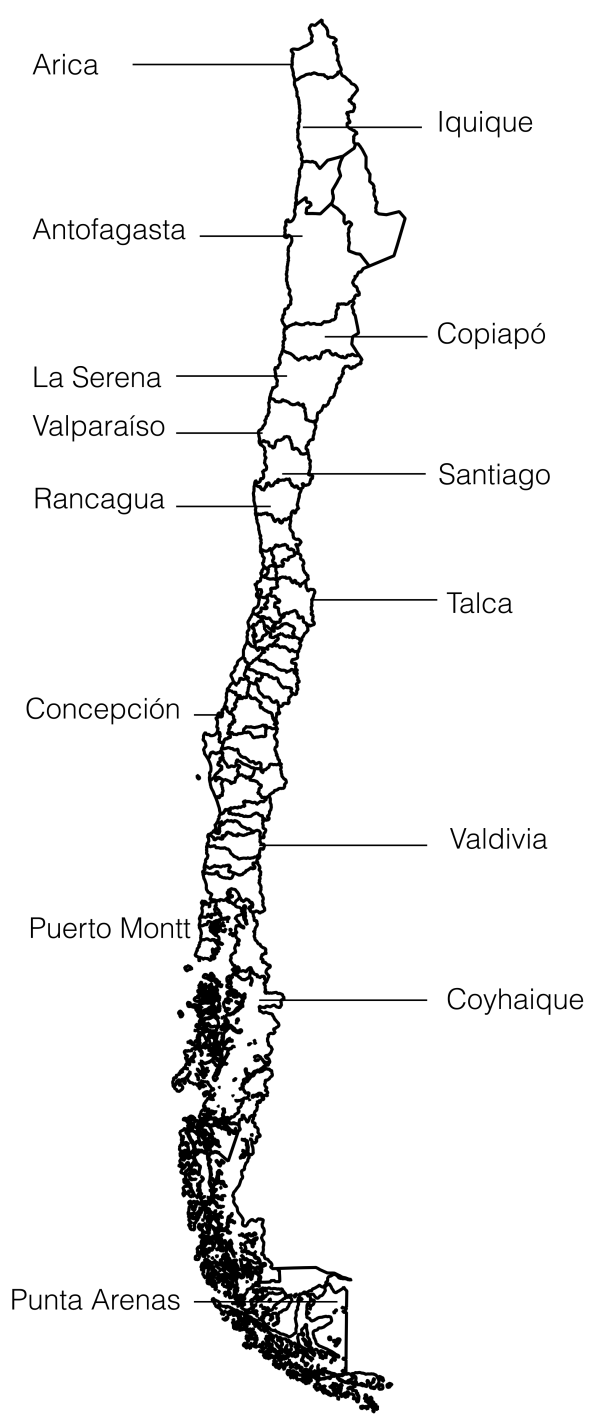

Notes: Labels for regional capital cities are displayed

Figure 1: Functional labor market areas for Chile

of significant economic transformation in Chile paralleling its transition to a globally integrated, market-driven system from a closed, centrally-planned economy. Drawing on evolutionary economic geography (Boschma, Frenken 2006) and economic complexity theory (Hidalgo, Hausmann 2009), the resource described above offers the possibility to enhance our understanding of the robustness, plasticity, niche construction, and evolvability of regional economic systems, i.e., how regional economic systems maintain certain functionalities, adapt, shape their immediate environments, and evolve in response to environmental disturbances (Martin, Sunley 2015).

The proposed resource can also be employed to trace the evolution of the interaction between labor demand and supply components in Chilean labor markets over three census periods, extending prior analysis (Rowe 2013, 2014, Rowe, Bell forthcoming). A labor market account (Rowe 2013) and a panel vector autoregression approach (Blanchard et al. 1992) can be implemented to identify the major routes of regional labor market adjustment, the way regional labor markets adjust to shifts in employment, and relative importance of geographic mobility processes, such as internal migration and commuting, play in regional labor markets. Such analyses have the potential to guide regional labor market policy development by providing evidence on the responsiveness of these processes to job creation and its potential leakages to non-local workers. 


\section{Acknowledgement}

This work was supported by the Spanish Ministry of Economy and Competitiveness [grant numbers CSO2011-29943-C03-02 and CSO2014-55780-C3-2-P, National R\&D\&i Plan] and the Chilean National Commission for Scientific and Technological Research through its human capital development program.

\section{References}

Blanchard OJ, Katz LF, Hall RE, Eichengreen B (1992) Regional evolutions. Brookings Papers on Economic Activity 1[1]: 1-75. CrossRef.

Boschma R, Frenken K (2006) Why is economic geography not an evolutionary science? towards an evolutionary economic geography. Journal of Economic Geography 6[3]: 273-302. CrossRef.

Casado-Díaz JM, Martínez-Bernabéu L, Rowe F (2017) An evolutionary approach to the delimitation of labour market areas: an empirical application for Chile. Spatial Economic Analysis: 1-25. CrossRef.

Hidalgo C, Hausmann R (2009) The building blocks of economic complexity. Proceedings of the National Academy of Sciences 106[26]: 10570-10575. CrossRef.

Martin R, Sunley P (2015) On the notion of regional economic resilience: conceptualization and explanation. Journal of Economic Geography 15[1]: 1-42. CrossRef.

Martínez-Bernabeu L, Flórez-Revuelta F, Casado-Díaz J (2012) Grouping genetic operators for the delineation of functional areas based on spatial interaction. Expert Systems with Applications 39[8]: 6754-6766. CrossRef.

OECD - Organisation for Economic Cooperation and Development (2009) Territorial reviews: Chile 2009. OECD publishing, Paris, France

Rowe F (2013) Spatial labour mobility in a transition economy: Migration and commuting in Chile. PhD thesis, school of geography, planning and environmental management, The University of Queensland, Brisbane, Australia. CrossRef.

Rowe F (2014) Micro and macro drivers of long-distance commuting in Chile: The role of spatial distribution of economic activities and population. paper presented at the 53rd congress of the Western Regional Science Association, San Diego, CA

Rowe F, Bell M (2013) Creating an integrated database for the analysis of spatial mobility in Chile. Working paper 02/2013, Queensland centre for population research, school of geography, planning and environmental management, The University of Queensland, Brisbane, Australia

Rowe F, Bell M (forthcoming) The drivers of long-distance commuting in Chile: The role of spatial distribution of economic activities and population. In: Poot J, Roskruge M (eds), Regional science perspectives on population change and impacts in Asia and the Pacific. Springer 